\title{
'Mercy killing': when is it justified, and what is the nurse's ethical responsibility?
}

\author{
Smrt iz milosti: njena utemeljenost in etična odgovornost medicinske sestre
}

\author{
Alice Kiger
}

A recent suspected incident of euthanasia at a hospital in Ljubljana (RTV SLO, 2015) has highlighted important questions about the ethics of such acts. That incident was reported as a deliberate intervention to bring about death, namely the administration of lethal drugs to an elderly patient who was unconscious following a stroke and it was apparently not performed at the patient's request. If this was the case, such an act of euthanasia would be active and non-voluntary (Butts \& Rich, 2005, p. 235). It has been referred to in the media as 'unlawful' (Slovenian Press Agency, 2015), but beyond that, its moral status is of ethical concern. Two key questions nurses need to consider are these: 1) was the act ethically justifiable? and 2) what is the nurse's responsibility in such a case?

\section{Ethical justification}

An argument in support of the act could be constructed along the lines of beneficence and non-maleficence (Butts \& Rich, 2005, pp. 12-13). If the patient had no hope of recovery and might spend further weeks or months in discomfort, living a life devoid of value, ending that life would be an act of kindness (it would be beneficent) and would prevent needless pain and suffering (it would be non-maleficent). Such an argument assumes, of course, that the physician can accurately predict that there is no chance of recovery, and (since the patient is unconscious and cannot speak for himself) that the physician knows that the patient's potential quality of life, if he did survive, would be such that he (the patient) would prefer death.

It is generally considered acceptable for physicians to prescribe an analgesic strong enough to relieve severe pain, even if the dose may hasten death - the doctrine of double effect (Johnstone, 2008, p. 278). This justification hinges on the intent of the physician, which must be to relieve pain, not to cause death, although it is accepted that death may occur as a by- product. This does not seem to have been the case in the recent incident, because it was reported that potassium as well as morphine was injected, so death was the evident intention.

In responsetothecontention that the act wasnonetheless beneficent and non-maleficent, one could counter with the principle of Kant's categorical imperative (Kuhse \& Singer, 2006, p. 4). According to this, we must only carry out acts if we would wish the maxim that supports them to be a universal law - in other words, we would be happy for the same act to be carried out in all similar situations. In the present case, this would mean we would think it was right to administer lethal drugs whenever an elderly patient is unconscious following stroke. It is unlikely that we would concede this maxim; its absurdity is evident. Another counter-argument might be to cite the principle of autonomy, according to which the patient has the right to decide such matters for himself. It appears that in the recent case the patient himself had not expressed a wish for euthanasia. It seems highly risky to accept that a physician has the right to decide to kill a patient because he/she thinks the patient may not recover an ideal quality of life, even with the potential concurrence of the family, who could not accurately predict the patient's potential future condition themselves and could only rely on the judgement of the physician.

One route to resolving this quandary is to take the decision out of the hands of an individual doctor, such as by requiring other physicians or suitably qualified professionals (who do not know the patient and can be more objective) to agree to the decision, or by having in place an ethical committee to which the matter can be referred for a decision.

\section{The nurse's responsibility}

Whether or not the decision itself is justified, there remains the issue of the nurse's role. How this

Dr Alice Kiger, Honorary Senior Lecturer, Retired Director, Advanced Studies in Nursing \& Midwifery, Division of Applied Health Sciences, University of Aberdeen, Scotland, and Associate Professor, Faculty of Health Care Jesenice, Slovenia

Correspondence e-mail/Kontaktni e-naslov: a.kiger@abdn.ac.uk 
is viewed depends, at least in part, on the view of society regarding the place of nurses, as well as the view of the nursing community about its own place. In most Western countries, nursing is in the process of establishing its identity as a profession, though the rate of progress varies among countries. One hallmark of a profession is accountability. In its web pages (Nursing and Midwifery Council, 2015a), the United Kingdom (UK) Nursing and Midwifery Council (NMC) states, "Accountability is integral to professional practice (...) [Nurses] need to be able to justify the decisions they make." The 2008 NMC Code states, "As a professional, you are personally accountable for actions and omissions in your practice, and must always be able to justify your decisions." (A new edition of the NMC Code will come into effect on $31^{\text {st }}$ March 2015 (Nursing and Midwifery Council, 2015b). Curiously, the word 'ethics' has been removed from the title and is mentioned in the body of the Code only in relation to advertising and publishing.) The Code of the International Council of Nurses states, "The nurse carries personal responsibility and accountability for nursing practice" (International Council of Nurses, 2012, p. 3). The statements from these Codes leave little doubt: the nurse who carries out a procedure she/he believes to be wrong has breached her/his professional duty, is accountable for that action and must take responsibility for its consequences. This means it is not sufficient to say, in justification, "It's not my fault - the doctor ordered it."

In a country where nursing is not yet universally acknowledged to be a profession, and in which physicians expect nurses to implement orders unquestioningly, it might be argued that nurses carry less responsibility for such an act. However, even as long ago as 1955, in the United States of America, Harmer and Henderson stated in their classic nursing textbook that "professional loyalties should never take precedence over the welfare of the patient" (Harmer \& Henderson, 1955, p. 105). This implies that if the nurse believes an action to be detrimental to the patient's interest, she/he should refuse to carry it out. The Code of Ethics for Nurses and Nurse Assistants of Slovenia (Nurses and Midwives Association of Slovenia, 2005) supports this view. Under Principle $\mathrm{V}$, it states, "In their professional practice, the nurse is independent and autonomous and has a responsibility to their own conscience, their patients and society" (p. 12), and under Principle VI, "The nurse adheres to the principles of professional conduct and refuses any procedure that could, in their professional and ethical opinion, be unethical and harmful for the patient" (p. 13). In the recent reported case in Ljubljana, it appears that the nurse believed the administration of the lethal drugs to be wrong, and questioned the physician, but administered them anyway.

This suggests the question: what should this nurse have done? It is easy to reply, 'She should have refused', but that may not be easy when such a circumstance arises. Pressure from the physician, who may see himself as superior and believe that he should be obeyed, may be difficult to resist. A nurse in such a situation needs to be confident of appropriate support. This implies an ethical responsibility on the part of nursing management and the hospital itself. What policies are in place to cover such circumstances? What are the attitudes of persons in leading positions? What mechanisms are in place for nurses to rely on?

Turning to the literature for helpful evidence, it is interesting to note that although much has been written about some aspects of euthanasia, there is little about the nurse's obligation, and right, to refuse to carry out a physician's order for 'mercy killing' drugs if the nurse believes it to be wrong. Considerable attention in recent literature is devoted to issues surrounding physician-assisted suicide and 'advance directives' (active voluntary euthanasia) (van Bruchem-van de Scheur, et al., 2008; Bartels \& Otlowski, 2010), and to issues regarding the treatment of disabled or terminal infants (Catlin, et al., 2008; Jotkowitz, et al., 2008; Manninen 2008). There is also attention given to specific incidents in which nurses themselves have decided to carry out acts of euthanasia, such as the case of Mary Rose Robaczynski, a nurse in Baltimore, USA, who disconnected ventilators of patients in an intensive care unit (Hendricks, 1979, p. 1). Some of the scant existing literature regarding nurses' carrying out physicians' orders for euthanasia focuses on the role of nurses under National Socialism in Germany, such as the excellent and sobering article by Hoskins (2005) in Nursing Ethics. An article by Inghelbrecht and colleagues (2010) reports a study of the participation of nurses in carrying out active euthanasia that was sometimes voluntary but sometimes non-voluntary; however, it focuses on the legality of the nurse's actions and does not mention whether nurses had reservations about their actions or what their views were about the justifiability of the euthanasia.

Thus there appears to be a gap in the literature, both of research investigating nurses' experiences, opinions, education, etc., in this realm, and of cogent critical discussion of the philosophical and ethical foundations of the relevant issues. This may reflect a lack of attention on the part of the nursing profession and its leaders, of nurses themselves, of hospital administrators, and others in positions of influence. It suggests that much more needs to be done to educate practicing nurses, their managers, the institutions within which they work, and the societal organizations that regulate them, to ensure that nurses and those who support their work are aware of and knowledgeable about the issues, and can rely with confidence on having access to the right resources when they are needed. It is foolish, and unfair to the communities we serve, to wait for drastic events to occur before we give sufficient attention to these vital matters. 


\section{Slovenian translation/Prevod v slovenščino}

Nedavni primer suma evtanazije vljubljanski bolnišnici (RTV SLO, 2015) je v ospredje postavil pomembna vprašanja o etiki takih dejanj. Pri primeru je šlo za zavestno posredovanje $\mathrm{z}$ namenom povzročiti smrt, natančneje za dajanje smrtonosnih odmerkov zdravil starejšemu bolniku, nezavestnemu po kapi, pri čemer leto ni bila bolnikova prošnja. Evtanazija bi lahko bila torej aktivna in neprostovoljna (Butts \& Rich, 2005, pp. 235). V medijih so jo sicer označevali za "nezakonito « (Slovenian Press Agency, 2015), vendar gre pri moralnem statusu dejanja za etično vprašanje. Medicinske sestre si morajo odgovoriti na ključni vprašanji: Ali je bilo dejanje etično upravičeno? in Kakšna je $\mathrm{v}$ tem primeru odgovornost medicinske sestre?

\section{Etična upravičenost}

Argument v prid takega dejanja bi lahko temeljil na načelih dobrodelnosti in neškodovanja (Butts \& Rich, 2005, pp. 12-13). Če ni upanja za ozdravitev in bi bolnik več tednov ali mesecev živel v neudobju, njegovo življenje pa bi bilo brez vrednosti, je končanje takega življenja dejanje iz dobrote (je »dobrodelno«), ki prepreči nepotrebno bolečino in trpljenje (je neškodovalno). $\mathrm{V}$ skladu $\mathrm{s}$ takšnim argumentom zdravnik pravilno predvideva, da ni možnosti za ozdravitev in (ker je bolnik nezavesten in ne more izražati svoje volje) da bi bila $\mathrm{v}$ primeru preživetja bolnikova kakovost življenja takšna, da bi sam raje izbral smrt.

Načeloma velja za sprejemljivo, da zdravnik predpiše za lajšanje močne bolečine dovolj močan analgetik, čeprav z odmerkom lahko pospeši smrt - to imenujemo doktrina dvojnega učinka (Johnstone, 2008, p. 278). Ta utemeljitev je osnovana na zdravnikovi nameri lajšanja bolečine, in ne povzročitve smrti, čeprav velja, da smrt lahko nastopi kot stranska posledica. Zdi se, da v nedavnem primeru ni bilo tako, saj sta bila vbrizgana tako morfij kot kalij, zato je očitno, da je bila smrt povzročena namerno.

Trditvi, da je bilo dejanje kljub temu dobrodelno in neškodljivo, lahko nasproti postavimo Kantovo načelo kategoričnega imperativa (Kuhse \& Singer, 2006, p. 4). $\mathrm{V}$ skladu s tem načelom lahko tako delujemo samo, če želimo, da bi maksima delovanja veljala kot načelo splošne zakonodaje - $\mathrm{z}$ drugimi besedami: če bi želeli, da se isto dejanje zgodi v vseh podobnih situacijah. V konkretnem primeru to pomeni, da bi se nam zdelo pravilno dajati smrtonosne odmerke zdravil, kadar koli je ostareli bolnik nezavesten po kapi. Najbrž se s tako maksimo ne bi strinjali, saj je njena absurdnost očitna. Drugi protiargument je lahko načelo avtonomije, $\mathrm{v}$ skladu s katerim ima pacient sam pravico odločati o takih stvareh. Zdi se, da $\mathrm{v}$ tem primeru pacient ni izrazil želje po evtanaziji. Zelo tvegano bi bilo zagovarjati stališče, da ima zdravnik pravico ubiti bolnika, ko misli, da le-ta ne bo imel več idealne kakovosti življenja, pa četudi ob soglasju bolnikove družine, saj bližnji sorodniki ne morejo natančno predvideti bolnikovega možnega stanja $\mathrm{v}$ prihodnosti in so glede tega odvisni od zdravnikove presoje.

Eden od možnih načinov razrešitve kočljivega položaja je, da odločanja ne prepustimo posameznemu zdravniku, temveč da se mora $\mathrm{z}$ njegovo odločitvijo strinjati več drugih zdravnikov ali primerno izobraženih strokovnjakov (ki pacienta ne poznajo in so tako lahko bolj objektivni) oz. da se odločitev o tem poveri za to pristojnemu odboru za etiko.

\section{Odgovornost medicinske sestre}

$\mathrm{Ne}$ glede na upravičenost odločitve je vloga medicinske sestre še vedno problematična. Pogled na to je vsaj deloma odvisen od družbenega pogleda na položaj medicinskih sester ter pogleda medicinskih sester na svoj položaj. V večini zahodnih držav si zdravstvena nega prizadeva vzpostaviti svojo strokovno poklicno identiteto, pri čemer je stopnja napredka v različnih državah različna. Ena od ključnih lastnosti poklica je odgovornost. Svet zdravstvene nege in babištva (Nursing and Midwifery Council NMC) iz Združenega kraljestva na svojih spletnih straneh (Nursing and Midwifery Council, 2015a) navaja: »Odgovornost je sestavni del opravljanja poklica /.../. Medicinske sestre morajo biti sposobne upravičiti svoje odločitve." Svetov (Nursing and Midwifery Council) kodeks iz leta 2008 določa: »Kot strokovnjaki ste osebno odgovorni za dejanja in opustitve dejanj med opravljanjem poklica in morate biti vedno sposobni upravičiti svoje odločitve." Nova izdaja kodeksa bo začela veljati 31. marca 2015 (Nursing and Midwifery Council, 2015b). Nenavadno je, da besede "etika " ni več v naslovu in je omenjena samo $\mathrm{v}$ besedilu kodeksa $\mathrm{v}$ povezavi $\mathrm{z}$ oglaševanjem in objavami. Kodeks Mednarodnega sveta medicinskih sester navaja: »Medinska sestra ima osebno in zunanjo odgovornost $\mathrm{v}$ povezavi $\mathrm{z}$ izvajanjem zdravstvene nege « (International Council of Nurses, 2012, str. 3). Besedilo $\mathrm{v}$ kodeksih ne pušča dvoma: medicinska sestra, ki izvaja po njenem mnenju neprimeren postopek, krši svojo poklicno dolžnost in je za to dejanje odgovorna ter mora prevzeti odgovornost za posledice. To pomeni, da kot utemeljitev lastnega dejanja ni dovolj navesti: »Ni moja krivda - zdravnik je tako naročil.»

V državi, v kateri zdravstvena nega kot stroka še ni univerzalno priznana in kjer zdravniki pričakujejo, da bodo medicinske sestre brez ugovorov izvajale ukaze, bi lahko rekli, da ima medicinska sestra manj odgovornosti za tako dejanje. Toda že davnega leta 1955 sta v Združenih državah Amerike Harmer in Henderson $\mathrm{v}$ svojem standardnem učbeniku o zdravstveni negi navedli, da "poklicna zvestoba nikoli 
ne sme imeti prednosti pred dobrobitjo pacienta " (Harmer \& Henderson, 1955, p. 105). To pomeni, da če medicinska sestra misli, da dejanje pacientovim interesom škoduje, mora izvedbo takega dejanja zavrniti. Kodeks etike medicinskih sester in zdravstvenih tehnikov (Nurses and Midwives Association of Slovenia, 2005) se sklada s tem stališčem. Načelo V pravi: »Medicinska sestra je pri opravljanju svojega poklica $\mathrm{v}$ okviru svoje strokovne usposobljenosti samostojna in neodvisna ter za svoje delo odgovorna pred svojo vestjo, pacientom in družbo.« (p. 12), nadalje načelo VI navaja: »Medicinska sestra upošteva načela strokovnega ravnanja in odkloni vsakršen poseg, ki bi po njenem strokovnem in etičnem prepričanju in vesti lahko bil neetičen ali za pacienta škodljiv.« (p. 13). Zdi se, da je bila pri nedavnem primeru medicinska sestra prepričana, da je dajanje smrtonosnih zdravil napačno, in o tem vprašala zdravnika, vendar jih je kljub temu dala.

Poraja se vprašanje, kaj bi ta medicinska sestra morala narediti. Odgovor, da bi morala poseg zavrniti, je sicer preprost, vendar to morda $\mathrm{v}$ določenih okoliščinah ni preprosto storiti. Pritisku zdravnika, ki se ima za njej nadrejenega in je prepričan, da ga je treba ubogati, se je morda težko upreti. Medicinska sestra v takem položaju mora biti prepričana, da ima ustrezno podporo. To pomeni, da imata vodstvo medicinskih sester in uprava bolnišnice etično odgovornost. Kakšna načela delovanja veljajo v takih okoliščinah? Kakšen je odnos oseb na vodilnih položajih? Na kakšne mehanizme se lahko zanesejo medicinske sestre?

Ko pregledamo literaturo, da bi našli informativne primere, $\mathrm{z}$ zanimanjem opazimo, da o dolžnostih medicinske sestre in njeni pravici zavrniti izvajanje zdravnikovega ukaza za po njenem mnenju neupravičen "uboj iz usmiljenja" ni veliko napisanega, čeprav je veliko napisanega o drugih vidikih evtanazije. Precej pozornosti je namenjene temam, ki se tičejo samomora $\mathrm{z}$ zdravniško pomočjo in "vnaprejšnjih navodil « (aktivna prostovoljna evtanazija) (van Bruchem-van de Scheur, et al., 2008; Bartels \& Otlowski, 2010), in vprašanjem, ki se tičejo zdravljenja invalidnih ali na smrt bolnih majhnih otrok (Catlin, et al., 2008; Jotkowitz, et al., 2008; Manninen, 2008). Poleg tega so obravnavani tudi posamezni primeri, $\mathrm{v}$ katerih so se medicinske sestre same odločile, da bodo izvedle evtanazijo, med drugimi tudi primer Mary Rose Robaczynski, medicinske sestre iz Baltimora v Združenih državah Amerike, ki je odklopila ventilatorje pacientov na oddelku za intenzivno nego (Hendricks, 1979, p. 1). Del zelo omejene obstoječe literature o tem, kako medicinske sestre izvajajo zdravnikove ukaze za evtanazijo, se osredotoča na vlogo medicinskih sester v obdobju nacionalsocializma $\mathrm{v}$ Nemčiji, na primer odličen trezno napisan članek v Nursing Ethics (Hoskins, 2005). Inghelbrecht s sodelavci (2010) navaja raziskavo o sodelovanju medicinskih sester pri izvajanju aktivne evtanazije, ki je bila včasih prostovoljna, včasih pa neprostovoljna, vendar se osredotoča na legalnost dejanj medicinskih sester in ne omenja, ali so imele medicinske sestre zadržke in kakšni so bili njihovi pogledi na upravičenost evtanazije.

V literaturi je torej razviden primanjkljaj raziskav o izkušnjah, mnenjih, izobraževanjuipd. na tem področju ter strnjene kritične razprave o filozofskih in etičnih temeljih teh tem. Morda je to odraz pomanjkanja pozornosti združenj medicinskih sester in njihovih vodij, samih medicinskih sester, vodstev bolnišnic in drugih, ki so na vplivnih položajih. Očitno je treba pri izobraževanju medicinskih sester, njihovih vodij, ustanov, v katerih delajo, in stanovskih organizacij, ki urejajo njihovo delovanje, narediti še veliko več, da bodo medicinske sestre in tisti, ki podpirajo njihovo delo, te teme poznali, da bodo o njih poučeni in da bodo imeli dostop do zanesljivo pravih virov, ko jih bodo potrebovali. Nespametno in nepravično do skupnosti, ki jim služimo, je, da čakamo na drastične dogodke, preden tem pomembnim temam posvetimo dovolj pozornosti.

\section{Literature}

Bartels, L. \& Otlowski, M., 2010. A right to die? Euthanasia and the law in Australia. Journal of Law \& Medicine, 17(4), pp. 532-555. PMid:20329456

Butts, J. \& Rich, K., 2005. Nursing ethics - across the curriculum and into practice, Sudbury, Massachusetts: Jones \& Bartlett Publishers, pp. 12-13, 235.

Catlin, A., Volat D., Hadley, M.A., Bassir, R., Armigo, C., Valle, E., et al., 2008. Conscientious objection: a potential neonatal nursing response to care orders that cause suffering at the end of life? A study of a concept. Neonatal Network, 27(2), pp. 101-108. http://dx.doi.org/10.1891/0730-0832.27.2.101

PMid:18431964

Harmer, B. \& Henderson, V., 1955. Textbook of the principles and practice of nursing. $5^{\text {th }}$ ed. New York: The Macmillan Company, p. 105.

Hendricks, T.W., 1979. Gessner died from disconnection of respirator, examiner testifies, The [Baltimore] Sun, Saturday, March 10, p. 1.

Hoskins, S.A., 2005. Nurses and national socialism - a moral dilemma: one historical example of a route to euthanasia. Nursing Ethics, 12(1), pp. 79-91.

http://dx.doi.org/10.1191/0969733005ne759oa PMid:15685969

Inghelbrecht, E., Bilsen, J., Mortier, F. \& Deliens, L., 2010. The role of nurses in physician-assisted deaths in Belgium. Canadian Medical Association Journal, 182(9), pp. 905-910.

http://dx.doi.org/10.1503/cmaj.091881

PMid:20479043; PMCid:PMC2882450 
International Council of Nurses, 2012. The ICN code of ethics for nurses. Geneva: ICN.

Johnstone, M.J., 2009. Bioethics: a nursing perspective. Chatswood NSW, Australia: Churchill Livingstone/Elsevier, p. 278.

Jotkowitz, A., Glick, S, \& Gesundheit, B., 2008. A case against justified non-voluntary active euthanasia (The Groningen protocol). The American Journal of Bioethics, 8(11), pp. 23-26. http://dx.doi.org/10.1080/15265160802513085

PMid:19061103

Kuhse, H. \& Singer, P., 2006. Bioethics: an anthology. $2^{\text {nd }}$ ed. Malden MA: Blackwell Publishing, p. 4.

Manninen, B., 2008. Revisiting justified nonvoluntary euthanasia. American Journal of Bioethics, 8(11), pp. 33-35. http://dx.doi.org/10.1080/15265160802513168

PMid:19061107

Nurses and Midwives Association of Slovenia, 2005. The code of ethics for nurses and nurse assistants of Slovenia. Ljubljana: Nurses and Midwives Association of Slovenia, pp. 12-13.

Nursing and Midwifery Council, 2008. The code: standards of conduct, performance and ethics for nurses and midwives. London: Nursing and Midwifery Council.
Nursing and Midwifery Council, 2015a. Regulation in Practice. Available at: http://www.nmc-uk.org/Nurses-and-midwives/ Regulation-in-practice/ [7.3. 2015].

Nursing and Midwifery Council, 2015b. The Code: Professional standards of practice and behaviour for nurses and midwives. London: Nursing \& Midwifery Council.

RTV SLO, 2015. Doctor suspected of performing euthanasia on a dying patient gets suspended. Available at: http://www.rtvslo.si/ news-in-english/doctor-suspected-of-performing-euthanasiaon-a-dying-patient-gets-suspended/355291/ [21. 2. 2015].

Slovenian Press Agency, 2015. Did a doctor euthanize a dying patient? Available at: http://radiosi.eu/shows/english-news/ article/Did-a-doctor-euthanize-a-dying-patient// [21. 2. 2015].

van Bruchem-van de Scheur, G.G., van der Arend, A.J.G., Huijer Abu-Saad, H., Spreeuwenberg, C., van Wijmen, F.C.B. \& ter Meulen, R.H.J., 2008. The role of nurses in euthanasia and physician-assisted suicide in The Netherlands. Journal of Medical Ethics, 34(4), pp. 254-258.

http://dx.doi.org/10.1136/jme.2006.018507

PMid:18375675

Cite as/Citirajte kot:

Kiger, A., 2015. 'Mercy killing': when is it justified, and what is the nurse's ethical responsibility? Obzornik zdravstvene nege, 49(1), pp. 4-8. http://dx.doi.org/10.14528/snr.2015.49.1.58 